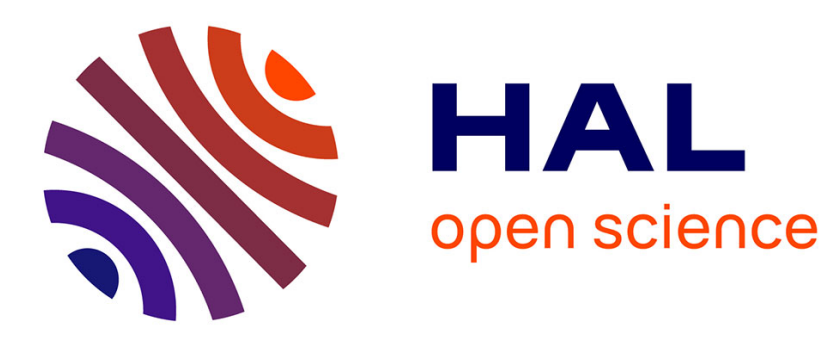

\title{
Error analysis for near-field EMC problems based on multipolar expansion approach
}

Zhao Li, François Tavernier, Arnaud Bréard, Laurent Krähenbühl, Damien

Voyer

\section{- To cite this version:}

Zhao Li, François Tavernier, Arnaud Bréard, Laurent Krähenbühl, Damien Voyer. Error analysis for near-field EMC problems based on multipolar expansion approach. IEEE CEFC, Nov 2016, Miami, FL, United States. pp.CD, 10.1109/CEFC.2016.7816346 . hal-01393474

HAL Id: hal-01393474

https://hal.science/hal-01393474

Submitted on 2 Apr 2019

HAL is a multi-disciplinary open access archive for the deposit and dissemination of scientific research documents, whether they are published or not. The documents may come from teaching and research institutions in France or abroad, or from public or private research centers.
L'archive ouverte pluridisciplinaire HAL, est destinée au dépôt et à la diffusion de documents scientifiques de niveau recherche, publiés ou non, émanant des établissements d'enseignement et de recherche français ou étrangers, des laboratoires publics ou privés. 


\title{
Error analysis for near-field EMC problems based on multipolar expansion approach
}

\author{
Z.Li $^{1}$, F.Tavernier ${ }^{1}$, A.Bréard ${ }^{1}$, L.Krähenbühl ${ }^{1}$ and D.Voyer ${ }^{1}$ \\ ${ }^{1}$ Université de Lyon - Ampère (CNRS AMR5005) ,ECL, 69134 Écully, France \\ zhao.li@doctorant.ec-lyon.fr
}

\begin{abstract}
In EMC behavior of power electronic converters, it is important to predict near-field coupling between complex components. A new measurement system based on multipolar expansion in spherical harmonics is proposed. The impact of the measurement uncertainties is studied in this paper.
\end{abstract}

Index Terms-Electromagnetic Compatibility, spherical harmonic, power electronics devices, quasi-static fields .

\section{INTRODUTION}

Characterization of electromagnetic interference (EMI) between two power electronic systems is an important activity in electromagnetic compatibility (EMC). However, EMC problems are currently treated after the production of a prototype, which causes additional costs and significant delays if the needed standards are not reached. In order to consider the compliance to EMC standards from the very beginning of the design phase, a method has been developed at Laboratoire Ampère [1] to predict near-field coupling between complex components. This predictive method is based on the multipolar expansion of the radiation in spherical harmonics on a field close to the element. With the measurement of magnetic flux all around, this element can then be represented by an equivalent punctual source composed of the elements of a multipolar expansion, which allows calculating the near-field coupling with other radiation elements.

\section{Multipolar Expansion: Theoritical ReCAlL}

The multipolar expansion in spherical harmonics is used for electromagnetic field representation satisfying Maxwell's equations. It allows decomposing any near field into an infinite sum of known standardized terms (dipole, quadrupole, octupole, etc.). For the near field studies $(<1 \mathrm{~m})$ in the $20 \mathrm{kHz}-20 \mathrm{MHz}$ range, the quasi-static approximation is suitable. Once the harmonic coefficients of two systems are identified, we can determine the coupling between them through the calculation of the mutual inductance [2]. It should be noted that the accuracy for the calculation of the mutual inductance is directly related to the choice of the maximum degree $\left(N_{\max }\right)$ used in the representation.

\section{Propagation Of UnCERTAinty}

In the previous work [1], a measurement method was only developed to determine the zero-order components of the first four degrees of the multipolar expansion $\left(N_{\max }=4\right)$, which is exclusively limited to axially symmetric sources.

A new automated measurement bench was designed at Laboratoire Ampère. This bench allows two rotational movements: a PVC arm in the vertical direction and a source support in the horizontal direction. A set of measurements can be done with the measuring positions uniformly distributed in a spherical surface with the measured source in the center. Thus, the dimension of the magnetic flux sensor and the length of the measuring arm can both be changed according to the size of the measured source and the accuracy required.

It should be noted that the final measurement results could be deviated by errors of different aspects [3]. These errors consist of electromagnetic noise during the measurements, the uncertainties in the sensor positions, disturbances due to the power wires, etc. An error analysis must be done in order to take into account all these uncertainties. The purpose of this paper is to study how these uncertainties propagate to the spherical harmonic components and also to the computed mutual inductance. These errors could be quantified in function of the confidence level which could be expressed as an interval $(x \pm \Delta x)$. The dynamic performance of the relative errors on the spherical harmonic components and the mutual inductance is the critical criterion for the choice of the measurement positions. With this in mind, several theoretical and numerical results which have already been established in the previous work could be verified experimentally such as the "optimal choice of the origin" [4] and the "effects of secondary sources" [5].

\section{CONCLUSION}

A new measurement system is proposed at Laboratoire Ampère to identify the radiation source in multipolar expansion with both zero- and non-zero-order components. Extended results of the error analysis of this multipolar expansion method will be detailed in the extended paper.

\section{REFERENCES}

[1] T. Q. V. Hoang, A.Bréard, and C. Vollaire, Near Magnetic Field Coupling Prediction Using Equivalent Spherical Harmonic Sources, IEEE Trans. on EMC, Vol. 56, n6, pp. 1457-1465, 2014

[2] B. C. Brock, Using vector spherical harmonics to compute antenna mutual impedance from measured or computed fields, SANDIA Report, DOI: 10.2172/763320, 2001.

[3] S.V.Gupta Measurement uncertainties, Springer Heidelberg Dordrecht London New York 2012.

[4] Z.Li, F.Tavernier,A.Bréard,L.Krähenbühl and D.Voyer Study of the choice of the origin in spherical harmonics expansion for magnetic near-field sources, APEMC May 18-21 2016, Shenzhen, China.

[5] Z.Li, F.Tavernier,A.Bréard,L.Krähenbühl and D.Voyer Study of the limitation of a new predictive method for near-field EMC problems with a multipolar expansion approach, EMF April 12-24 2016, Lyon, France. 